\title{
A Distorting Mirror: Major Media Coverage of Americans' Tax Policy Preferences
}

\author{
Daniel Chomsky*
}

Working Paper No. 73

April $17^{\text {th }} 2018$

\begin{abstract}
Over the last four decades, Americans have consistently told pollsters that they favor higher taxes on business and the wealthy, even as tax policy has moved sharply in the other direction. Political scientists and political commentators regularly assume that elected officials respond to the preferences of citizens, despite recent findings that the correlations between public preferences and policy outcomes disappear when accounting for the preferences of the wealthy. This paper quantitatively assesses the failure of democratic responsiveness on this issue. It examines coverage of American's tax policy preferences in two major national newspapers, the New York Times and USA Today. Both newspapers exhibit nearly identical behavior: they privilege elite sources, ignore the voices of ordinary citizens, and misrepresent public preferences. They also highlight expressions of public opposition to taxes and suppress evidence of persistent public support for higher taxes on business and the wealthy.
\end{abstract}

\footnotetext{
* Daniel Chomsky is Associate Professor of Political Science at the University of Texas Rio Grande Valley. daniel.chomsky@utrgv.edu Research support from the Institute for New Economic Thinking is gratefully acknowledged.
} 
Keywords: Tax Policy, Democratic Theory, Mass Media, Public Opinion, New York Times, USA Today

JEL Classifications: D72, H20, H30, L82, M38, P16, Z1 


\section{Introduction}

The increase in inequality in America over recent decades has belatedly captured the attention of the mass media and political elites. The issue figured prominently in the 2016 presidential election. The public overwhelmingly favored action to address it, according to public opinion surveys. And Donald Trump posed as an advocate for ordinary people, while simultaneously proposing large new tax cuts for corporations and the wealthy. Yet Trump was not entirely unique in adopting this particular stance. As the New York Times noted early in the campaign, a number of candidates expressed concern over the problem without offering to do anything meaningful about it (Scheiber 2015).

The practical indifference of elected officials to the issue is puzzling, given the evidence about public opinion, and cries out for explanation. This study seeks to throw light on the question. It focuses on American tax policy since that represents a plausible response to inequality. The specific question the paper focuses on is whether the mass media represents public preferences or suppresses them, in preference to some other interests.

Let us begin by considering some possible explanations. Perhaps nothing has been done about inequality in recent years because there is nothing to do about it. Some analysts, for example, claim that inequality is an inevitable or intractable feature of the global economy, or at least impossible to alter at acceptable cost (Cowen 2013). Eduardo Porter (2016) echoed this view in the New York Times and proposed that "we should just learn to stop worrying and love it."

Or it may be that Americans are just unwilling to support policies that would reduce inequality. Policy may reflect public preferences generally (Stimson, Mackuen, and Erikson 2002). Progressive tax policies might effectively address the issue without adversely affecting 
economic growth (Diamond and Saez 2011, Piketty 2014, Atkinson 2015). But perhaps tax policy is particularly sensitive to public preferences (Brownlee 1996). The tax system may reinforce inequality because the American people hate taxes, as Sven Steinmo (1993) argued. Graetz and Shapiro (2005) found wide public support for estate tax repeal, even though few Americans have to pay it. And Martin Gilens (2012), who demonstrated that policy makers generally favor the wealthy over majority opinion, cited the Bush tax cuts of the early 2000s as an example of a public consensus for tax cuts. Public opposition to taxes is seen as so powerful that even the advocates of economic equality sometimes abandon progressive taxes as a remedy (Kenworthy 2013).

In fact, American views about taxes are more complicated. Americans rarely list taxes among their highest priorities, and they know few details of tax policy proposals (Graetz and Shapiro 2005). So they may passively acquiesce to any number of tax policy outcomes, even policies that contradict their underlying preferences. And while Americans may hate taxes generally, they may also favor higher taxes on the wealthy. Steinmo observed that "citizens prefer taxes that someone else pays," and he concedes that business and the wealthy "are the natural targets for tax hikes" (p. 17). Yet policy has moved in exactly the opposite direction in recent decades, with sharp tax cuts for corporations and the wealthy, and tax increases on other Americans to make up some of the shortfall. Joel Slemrod (2006) found that Americans have supported regressive tax proposals because they incorrectly believed that they would move policy in more progressive directions. Bartels (2008) noted the conflict between Americans' expressed preferences and their apparent support for the steeply regressive Bush tax cuts, and he concluded that ordinary people were unable to recognize their own interests in specific policy proposals. 
However, it may be that policy choices are only distantly related to true public preferences. Hacker and Pierson (2005) argued that Americans preferred more generous social welfare programs over the Bush tax cuts when given reasonable alternatives in public opinion surveys. Perhaps their example shows that ordinary people are simply asked to choose among unsatisfactory policy proposals dictated by others.

The mass media may contribute to outcomes of this sort. They may facilitate democratic responsiveness by representing public preferences. Or they may obstruct responsiveness by establishing and reinforcing the distance between public preferences and policy choices. The media may misrepresent the nature of policy proposals, limit the range of political choices, and exclude ordinary citizens from public discussion.

Studies of the mass media have often assumed that people are relatively immune to media influence, so they have downplayed the possibility that media may undermine democracy. Personal beliefs, runs one line of argument, may be deeply held and relatively fixed. People may resist media messages (Neuman et al. 1992) or interpret them in the context of their own world views (Gamson 1992). And the media may simply conform to existing public sentiment rather than try to shape it (Gentzkow and Shapiro 2006, Hamilton 2004, Zaller 1998). Consequently many dismiss the media's impact on citizens or political outcomes, following a long tradition (Lazarsfeld et al. 1948, Berelson et al. 1954, Klapper 1961).

An alternative perspective is that the mass media may exert influence by focusing attention on some ideas over others (Cohen 1963, McCombs and Shaw 1972, Iyengar and Kinder 1987, Chomsky and Barclay 2013). Studies have focused on the media's direct impact on citizens themselves. Certainly media attention may affect the importance citizens attribute to issues, the political opportunities and policy options that people perceive. But media coverage may also 
affect the choices political elites consider, the policies they adopt, and the questions pollsters ask after the fact. If the media highlight some policy choices and downplay or suppress others, they may affect public perceptions and policy outcomes at the same time.

The choices media outlets make in this regard will depend on the nature of media institutions and the incentives and pressures they face. According to one common view, the mass media seek profits by maximizing audiences (Hamilton 2004, Gentzkow and Shaprio 2006). The media will therefore seek to please audiences by adopting and promoting the views and preferences of ordinary citizens. Gentzkow and Shapiro offered the most sophisticated test of this proposition. Their principal evidence was that newspapers adopted partisan phrases associated with either congressional Democrats or Republicans corresponding to the partisan distribution of campaign contributions in the zip codes in which the newspapers circulated. Gentzkow and Shapiro assumed that campaign contributors represent newspaper audiences (2006, page 10). But campaign contributors are a narrow segment of the population, and far wealthier than ordinary citizens. It could be that Gentzkow and Shapiro only captured signals between elected officials and wealthy campaign donors instead. Media outlets may simply convey elite preferences to other elites.

There are reasons to think that media are more likely to represent elites than audiences and ordinary citizens. Even with the rise of new media, many media markets remain highly concentrated or have become more concentrated, and media firms and outlets may be insulated from direct competition and audience demands (Bagdikian 2004, Bennett 2005, McChesney 1999). Media owners may pursue their own preferences, and they may respond to government officials, corporate advertisers, and other prominent actors instead (Herman and Chomsky 2002, Chomsky 1999, Chomsky 2006). Media may promote elite views rather than public preferences. 
And this may be particularly likely when elite interests diverge from the views of ordinary citizens.

The media's response to these conflicting pressures may be reflected in the sources that media outlets choose and in the positions that these sources express. Existing studies confirm that elite sources predominate. Sigal (1973) showed that government officials represented roughly two thirds of sources cited in leading newspapers. Bennett (1990) argued that the media indexed the range of official or elite views and ignored citizen preferences even when broad majority opinion diverged from elite preferences. Gamson (2001), in contrast, found that the media covered ordinary people and social movements in some instances and ignored them in others. Gamson did not fully account for these differences. But Chomsky and Barclay (2013) suggested that media may be more sensitive to ordinary people social movements when they have the sympathy of media owners and other elite actors.

The mass media may favor elites over citizens on tax policy to the degree that public preferences and elite preferences differ on this issue. Americans have consistently favored higher taxes on corporations and the wealthy for the last four decades. Yet taxes on business and the rich have fallen substantially during this period. Page, Bartels, and Seawright (2013) identified tax policy as one of the issues on which elites and ordinary citizens disagree. Citizens may have clear and coherent preferences on this issue, but their views may not be represented in the mass media, considered in political discussions, or reflected in policy outcomes. The media may not change public preferences in these instances, but they may successfully exclude citizen voices from public discussions of tax policy. Media practice may explain why public opinion and policy have diverged on this issue. 


\section{Evidence and Methods}

The American people may oppose taxes generally, but they may favor higher taxes on corporations and the wealthy at the same time. To address this possibility, I collected all questions on taxes from the iPOll database, and I concentrated on a series of questions that explicitly distinguished between taxes on the wealthy and taxes on other groups. These questions, in almost identical language, ask whether taxes are too high or too low for lower income people, middle income people, higher income people and corporations. And they have been repeated frequently from 1977 to the present. They are particularly valuable because they capture the contrast between general opposition to taxes and support for higher taxes on the wealthy. And they provide a consistent measure of opinion over a long period of time. I avoided alternative questions that were worded differently, particularly ones that assumed certain facts and issues (but not others) or asked about tax increases to pay for specific purposes like health care, environmental protection, or to reduce budget deficits. Responses to these questions may be affected by judgments on the purposes of the tax proposal and not the tax itself.

I compared public preferences to media representations of opinion. To measure the attention and prominence the media give to public preferences, I focused on front page coverage in two national newspapers, the New York Times and USA Today. I included the New York Times because the Times is the most comprehensive daily newspaper in the United States, it has a wide audience of its own and because it is closely followed at other media outlets. Other media outlets are often thought to echo the Times' coverage decisions. So the Times may effectively represent the mainstream media as a result. Extreme and insular media outlets have emerged on the right in recent years, as Faris et al (2017) show. Still, the Times remains among the news organizations most cited by other media outlets and the most shared on social media as well. Despite its 
national reach, the Times' principal audience may be more liberal, wealthier, and more educated than Americans generally. If the newspaper responds to its own primary audience it may be more likely to promote progressive taxes in response to the liberal preferences of its audience, or it may be less likely to include the voices of ordinary Americans and it may discourage progressive taxes in response to the background and interests of its audience.

To take these possibilities into account, I also included USA Today, because its more mass-based audience is likely not be as liberal, wealthy, or educated as the Times elite audience. If it responded to its audience it might more closely reflect the preferences of ordinary Americans, it might eschew elite sources, and it might privilege ordinary people as sources instead. These potential differences among newspapers may be overstated. A recent study of newspaper audiences by the Pew Research Center found that newspaper audiences do not differ significantly. New York Times readers are more likely to be liberal than Americans in general, but all newspaper audiences tended to be liberal, even for the most conservative newspapers. Times readers are wealthier than the average American, but most Times readers were far from the upper reaches of the American income distribution. If the Times and USA Today respond to their audiences, they should be expected to be more supportive of progressive taxes than the average American.

I collected every front page article in the New York Times and USA Today that mentioned taxes from either the Proquest Historical Newspaper or the LexisNexis databases. I counted and evaluated every reference to public preferences to determine whether the two newspapers fully represented public sentiment. And I concentrated on five years, four years with major changes in tax policy, 1981, 1990, 2001, and 2012, two with tax cuts, and two with tax increases on the wealthy, three during Republican administrations, and one with a Democratic one. I also 
included 2016 to capture Donald Trump's presidential campaign and to foreshadow the prospects for the Trump tax cuts in in 2017. I reviewed the New York Times for all five years and USA Today for three years, 1990, 2012, and 2016.

The representation of competing views on taxes may reflect the patterns of influence over national newspapers. If newspapers are responsive to audiences, they might be expected to highlight ordinary people as sources. Or if they are more sensitive to elites and their preferences, they might privilege government officials and other prominent actors instead. To determine who received attention from the national newspapers, I collected all references to specific actors and their views. To evaluate the claim that media respond to audiences, I coded ordinary citizens broadly, counting all statements by ordinary people, all references to public opinion surveys, and all references to popular votes that are explicitly or inferred to be about taxes. Since previous studies have found that government officials dominate as sources, I also counted all official statements on taxes and all references to official actions that indicate a view on taxes.

Unfortunately, previous studies have been vague about the nature of non-official sources, often including all non-official sources in one broad, amorphous category. One exception to this practice was Benjamin Page's (1996) study of op-ed columns before the Persian Gulf War in 1991. Page distinguished between business sources, experts, labor union representatives, and others. Since it is important to distinguish between ordinary citizens and other non-official sources, I adopt similar categories as well. The mass media may pay more attention to organized groups than individual citizens, so I counted all references to labor unions. And because media may respond to other elite interests, I counted references to business and experts as sources. $\mathrm{T}$

These categories may be ambiguous. Businesses may seek to influence tax policy through the mass media, but business figures may want to conceal their role in policy discussions. So 
they may present themselves and be identified by the newspapers as ordinary citizens. Experts may work for institutions funded by business or other interests. In fact, a large number of sources identified simply as economists were affiliated with Wall Street financial firms or other businesses. When sources were just described as economists or specialists with no explicit affiliation to business or labor unions I coded them as experts. When they were specifically affiliated with corporations I coded them as business sources. Unless there was sufficient evidence to determine otherwise, I adopted the newspapers' identification of these sources, while recognizing the possibility that they may not have been what they appeared to be.

\section{Public Opinion, Tax Policy and Democratic Responsiveness}

Figure 1 compares support for taxes on the middle class to support for taxes on corporations and the wealthy from 1977 through 2016. It is widely assumed that Americans dislike taxes. Sure enough, survey questions asking specifically about taxes on the middle class show nearly universal opposition. Support for higher taxes registered in the single digits. It never reached ten percent during the entire period.

At the same time, most Americans always support higher taxes on corporations and the wealthy. And this remained true even during major historical moments associated with anti-tax sentiment. In May 1978, a month before Proposition 13 passed in California signaling the emergence of a nationwide "tax revolt," 72 percent of Americans favored higher taxes on corporations and 76 percent favored higher taxes on the wealthy. In 1979, on the eve of Ronald Reagan's campaign for president, 75 percent favored higher taxes on the rich. Just after the large and regressive Reagan tax cuts were passed in 1981, 65 percent supported higher taxes on the rich in response to a slightly different Los Angeles Times question. 78 percent favored higher 
taxes on the rich and 69 percent favored higher taxes on corporations before Reagan was reelected in 1984. And 81 percent favored higher taxes on the rich and 86 percent favored higher taxes on corporations in December 1984 just after Reagan was reelected. 66 percent favored higher taxes on the wealthy in 1999 before George W. Bush was elected 2000. Support for taxes fell to its lowest point in 2010, at the height of Tea Party Movement, although even then 55 percent continued to favor higher taxes on the rich. And it recovered by 2012, with 62 percent favoring higher taxes on the rich and 64 percent favoring higher taxes on corporations.

After the rise in top income tax rate at the end of 2012, support for progressive taxes remained strong. And in 2016, as Donald Trump prevaricated on taxes, promising to eliminate the tax advantage for carried interest and endorsing tax cuts for business and the wealthy, 61 percent continued to favor higher taxes on the wealthy, 67 percent called for higher taxes on corporations, and 78 percent favored higher taxes on people with incomes over one million dollars. American attitudes on these issues remained remarkably consistent and coherent, exhibiting the features that Page and Shapiro (1992) identified as evidence that public opinion is real and meaningful.

Yet tax policy mostly moved in the other direction. Figure 2 compares public support for taxes on the wealthy with actual changes in the top income tax rate. While Americans wanted higher taxes on business and the wealthy (and lower taxes on the middle class), taxes on corporations and the rich declined. Social Security taxes and other regressive taxes increased. Tax policy was almost exactly the opposite of what people said they wanted in these respects. 


\section{National Newspapers and Public Opinion}

American tax policy has been inconsistent with Americans' expressed preferences.

Perhaps this is because the media misrepresented public preferences and suppressed public support for more progressive taxes. To address this possibility, I collected every reference to public opinion on taxes from the front page of the New York Times and USA Today, giving particular consideration to each reference to public opposition to taxes and each reference to public support for higher taxes on the rich. Figures 3 and 4 compare the results from the two newspapers.

A number of findings stand out. Figure 3 shows the total number of tax articles on the front pages of the two newspapers, the number that mentioned public opposition to taxes, and the number that acknowledged public support for higher taxes on business and the wealthy. As expected, the New York Times devoted much more attention to tax policy on its front page than USA Today. Nevertheless, practices at both newspapers were otherwise virtually identical. Both newspapers highlighted public opposition to taxes. Meanwhile, references to public support for higher taxes on business and the wealthy were extremely rare in the New York Times and vanished to near zero in USA Today.

The overriding uniformity is most apparent when the references are measured as percentages of all front page tax articles in the two newspapers, as represented in Figure 4. Both newspapers emphasized public opposition to taxes in about 15 percent of tax articles. Both mentioned public support for higher taxes in about 3 percent of tax articles. The two newspapers did not differ on the basis of their unique audiences, they did not reflect any liberal tendencies in their audiences. Indeed, their coverage did not reflect the views of the American population at all. 
The extent and significance of newspaper suppression of public support for more progressive taxes can be most clearly seen in the annual number of tax articles. Figure 5 includes all of the references to public preferences in the New York Times in each of five years. Figure 6 compares the total number in the Times and USA Today in each of three years. Both newspapers emphasized public opposition to taxes every year. The Times cited it in 92 articles in 1981, 77 in 1990, 40, in 2001, 63 in 2012, and 41 in 2016. The numbers declined over the years, probably due to format changes that reduced the number of articles on the Times' front page as well as shifts in coverage from public affairs to coverage of cultural trends, human interest stories, and the personal character of public officials (Patterson 1992, Diamond 1994). USA Today has been known for its preference for soft news over policy coverage since its founding in 1982, so it published far fewer tax stories than the Times every year. Still it found space to report public opposition to taxes as well, 26 articles in 1990, 19 in 2012, and 10 in 2016.

Meanwhile the national newspapers rarely mentioned public support for higher taxes on business and the rich. The Times published only one reference during 1981 when the Reagan tax cuts were debated and passed. It published none at all in 2001 when the Bush tax cuts were adopted. The Times had just two references in 2016. USA Today had only one.

The Times, at least, gave greater attention to public support for progressive taxes in years with tax increases. The Times published nine in 1990 and 21 in 2012. USA Today still mostly ignored public preferences, citing them in only three and six articles in 1990 and 2012. Even in those years the number of articles emphasizing support for tax cuts far exceeded the number acknowledging support for tax increases on the wealthy. And the overall imbalance reinforced the notion that Americans opposed taxes, just as it largely concealed public support for higher taxes on corporations and the wealthy. 
In 2012, the most closely balanced year, the ratio was 3 to 1 in favor of tax cuts. For the others the ratio was 9 to 1 or more. 99 percent of the references favored tax cuts in 1981, 95 percent did in 2016, and every single one favored tax cuts in 2001. The heavy emphasis on public opposition may have facilitated the passage of tax cuts in 1981 and 2001, while the virtually complete suppression of support for higher taxes may have precluded any consideration of the alternative. The publication of even a few references to progressive taxes, in contrast, may have encouraged the passage of tax increases in 1990 and 2012. And the suppression of public support for higher taxes in 2016 set the conditions for tax cuts in 2017.

The national newspapers ignored substantial evidence of public support for tax increases, including compelling survey data from prominent pollsters, as they promoted tax cuts on the front page. The Times described the California vote for Proposition 13 as part of a national revolt against taxes. 14 front page articles in June and July 1978 used some version of the phrase “taxpayers' revolt.” The Times reported its own survey finding opposition to property taxes. But it did not mention a Roper poll in May that found 72 percent support for higher taxes on corporations or another Roper poll in July that reported 76 percent support for higher taxes on the rich.

Before the 1980 election the Times claimed that there was a "consensus" in favor of business tax cuts (8-18-1980). It extended so far that even the AFL-CIO, which had previously been "doctrinaire in opposing tax relief for business" was now on board. The Times didn't mention any evidence that this consensus extended to the American people. And it didn't cite any polls either.

In both 1981 and 2001 the newspapers reinforced official efforts to pass large tax cuts with benefits skewed toward the wealthy. Upon his election in 1980 Ronald Reagan claimed a 
mandate to cut taxes, and the Times aggressively promoted this notion. The paper published 92 separate articles emphasizing public opposition to taxes in 1981. The Times also gave generous attention to business complaints that the proposed tax cuts did not go far enough, and business demands for additional tax cuts were subsequently incorporated into the legislation. The Times did not report the results of a Los Angeles Times survey that found nearly two thirds in support of higher taxes on the wealthy. It mentioned public support for more progressive taxes in only one article all year.

Within days after the passage of the Reagan tax cuts, Times coverage shifted abruptly, illustrating the arguments and sources that appeared in the Times and those that did not. ?What does this previous sentence mean? Businesses suddenly began to complain about increased federal budget deficits, and this concern did receive sustained attention. Over the period of about one month the Times featured 10 front page articles on business objections to rising deficits. Reagan administration officials and Republican in Congress complained that business should be more grateful for all the benefits they received from the tax cuts. House Minority Leader Robert Michel observed that "We gave them more than they ever dreamed... and you'd think there would be more of a quid pro quo." Republicans even briefly threatened to punish Wall Street with a windfall profits tax on finance, and then quickly retreated (9-10-1981, 9-11-1981). Yet not one business source proposed that the tax cuts for business and the wealthy be repealed despite their warnings about deficits.

There were far fewer stories on taxes in 2001 and fewer references to public opposition to taxes. References to public support for progressive taxes went from one in 1981 to absolute zero in 2001. The Times allowed some debate. There were supporters of the tax cuts and some opponents of tax cuts. Some objected to the size of the tax cut, and others opposed some aspects 
of the proposal. A group of prominent and wealthy individuals expressed opposition to the elimination of the estate tax specifically. The Times conceded at one point that "voters are not yet clamoring for tax relief" (2-28-2001) and later reported that the tax proposal did indeed have majority support (3-14-2001). And George Bush, speaking on behalf of the American people himself, recounted that the "waiters and waitresses" he had just encountered thanked him for the tax cut (6-1-2001). But the Times did not find anyone for its front pages to argue for lower taxes on ordinary Americans and higher taxes on corporations and the wealthy. That choice was not among those on offer.

In 2016, as in every other year, the Times emphasized public opposition to taxes and downplayed popular support for higher taxes on corporations and the wealthy. As in 1981 and 2000, attention was notably lopsided with 41 articles citing public opposition to taxes and only 3 noting public support for more progressive taxes. But this time it was in the context of an election widely seen as driven by populist unrest. One source for the otherwise typical imbalance was Hillary Clinton and her campaign. After all, Clinton campaigned for higher taxes on the wealthy herself. Yet she and her campaign repeatedly responded to the primary challenge from Bernie Sanders by insisting that Americans oppose taxes. Unnamed Clinton representatives told the Times that they regretted that they did not criticize Sanders even more for "the enormous costs and likely tax increases tied to his big-government agenda" as the Times put it (1-17-2016).

The Times helpfully promoted this theme. A week later, the Times warned that "Mr. Sanders risks easy caricature from Republicans as a tax-and-spend liberal who would turn the United States into a Scandinavian-style welfare state" (1-25-2016). And the paper appeared to conclude, citing "some Democrats," that Sanders "is too liberal and his proposed tax increases too toxic to win a general election" (2-12-2016). The Times devoted four front page articles to 
Clinton's claim that Sanders' tax increases would be unpopular with ordinary Americans. It never recorded a single instance in which Clinton argued that the American people favored higher taxes on the rich even though it was a significant promise of her campaign. And the Times never noted that the public sided with Clinton over Trump on this point either. While the Times repeatedly marveled at Trump's populist appeal, it never used its front page to juxtapose Trump's claim that he represented ordinary Americans with his support for unpopular tax cuts for business and the wealthy.

USA Today seemed indifferent to tax policy during the 2016 presidential campaign, as usual. It published 63 front page articles mentioning taxes. It addressed public attitudes in 11 articles, emphasizing public opposition to taxes in 10 of them. In that context, it seemed natural for USA Today to observe that Bernie Sanders' tax and other policies made him "so far left" that he wasn't even a member of the Democratic Party (2-1-2016). USA Today had little to say a about whether ordinary people found his proposals beyond the pale. The closest reference was from Citizens for Tax Justice Director Bob McIntyre, who suggested that Americans would not find current tax rates on business too high. This was the closest USA Today came to acknowledging public support for higher taxes on business during the entire year. The paper more directly cited the views of business leaders, including Verizon CEO Lowell McAdam, who called Sanders' charge that business avoids taxes "uninformed" and "contemptible" (4-15-2016). Donald Trump, meanwhile, who proposed sharp tax cuts for business and the wealthy, was described in USA Today by Republican Congressman Tom Marino as the tribune of "blue collar, hardworking taxpayers" who were sick of regulations and taxes (3-29-2016).

The newspapers gave more attention to public support for higher taxes in 1990 and 
2012, and elected officials raised taxes on the wealthy in both years. Perhaps even a small number of pro-tax articles have an effect on policy outcomes, or perhaps the newspapers only acknowledge public sentiment when it conforms to elite preferences.

The differences between 1996 and 2012 should not be exaggerated, however. The newspapers continued to emphasize public support for tax cuts. 77 front page stories in the Times reported public opposition to taxes during 1990. And the Times still downplayed public support for higher taxes on the rich. In May the Times reported strong support for higher taxes on the rich in its own survey. And exactly one month later, Richard Berke, commenting on the same Times poll, asserted that Americans "do not like higher taxes," but "they had become more resigned to the idea" (6-27-1990).

Still, 1990 is unusual in that there were some references to popular support for more progressive taxes. It could be that the public or the Times pressured government officials for higher taxes. Public support was relatively high by the end of 1990, but it was at normal levels earlier in the year. Or it could be that the Times responded to decisions already made by government officials. To test these possibilities I looked at the timing of official decisions and Times articles. There was not one single reference to public support for more progressive taxes for the first four months of 1990. President Bush expressed willingness to consider tax increases on May 7, and the Times released the results of its poll on May 27. President Bush and the Congress reached a budget agreement on September 30, including an increase in top individual income tax rate from 28 percent to 31 percent. 7 of 9 references to public support for more progressive taxes fell in the following month. In both instances officials moved first, and the Times responded to them. 
USA Today was certainly less likely to lead on the issue than the Times. Even after President Bush acknowledged that new taxes might be necessary, USA Today continued to insist that Americans opposed tax increases (5-11-1990). Indeed, all three references to public support for progressive tax increases came after the tax increases were passed by Congress and signed by the President. There can be only one interpretation: USA Today did not respond to public pressure for more progressive taxes; it did not promote the issue on its own; it merely ratified the decisions made by other elite actors.

Newspaper coverage of taxes differed most strongly in 2012, although more noticeably at the New York Times. Opposition to taxes still dominated coverage, as it always did. Sixty three front page stories in the Times mentioned public opposition to taxes. But the period stands out for the unusually high number of references to higher taxes on the rich. There were 21 front page stories on higher taxes for the rich in the Times, more than in any other year. There were only six in USA Today, but that was a high for that paper as well. It is not likely that the coverage was due to any change in public opinion. Public support for higher taxes on the rich was at 62 percent according to Gallup in April, absolutely high to be sure, but near its lowest level for the entire 40 year period. Perhaps it was due to the emergence of Occupy Wall Street in the fall of 2011. Or maybe it reflected the political agenda and electoral strategy adopt by President Obama and his reelection campaign. The explanation for this outcome may rest on the role and treatment of news sources at the national newspapers.

\section{Who Appears in the National Newspapers?}

The tone and direction of news coverage may reflect the positions adopted by sources in the news. Of course, the decision to select some sources over others is a power that news 
institutions have themselves, but by giving attention to others the outlets grant substantial influence to those actors as well. To determine who gained influence in this way, I counted every reference to the comments or actions on taxes recorded in the newspapers from a number of possible sources. Figure 7 compares the use of source in the New York Times and USA Today. Figure 8 shows the use of sources in the New York Times for each of five years. And Figure 9 has the sources for both papers for each of three years.

Again, the Times and USA Today chose almost identical sources. They did not reflect any differences in their audiences. The New York Times was no more likely to favor elite sources because of the elite background of its audience. And USA Today showed no more consideration for ordinary people because of its mass-based audience. Instead, both newspapers seemed to respond in similar ways to the same pressures and interests.

Not surprisingly, government officials dominated in both newspapers. They represented almost two thirds of news sources overall, 65.2 percent in the Times and 62.8 percent in USA Today. These numbers are consistent with previous studies (Sigal 1973), and they raise important questions about the relationship between officials, the mass media, and society. Gentzkow and Shapiro expected that elected officials will represent the views of their constituents. But officials may adopt positions far from their constituents, and as Bennett (1990) showed the media will go with the official sources and not the wishes of constituents. In that event, the national newspapers will be more likely to echo official views than represent citizen preferences. And it may explain why there is so little attention to public preferences for higher taxes on business and the wealthy.

All other actors were relatively insignificant by comparison. Still, some remained more important than others. Business represented the next most prominent source. Business figures 
accounted for 14.9 percent of sources in the Times and 12.1 percent of sources in USA Today. They accounted for 16.3 percent of sources in the Times in 1981, mostly to complain that the Reagan tax cuts were not large enough, 19.2 in 2012, and 17.9 percent in 2016 . The substantial number of business sources suggests that they might be a real alternative source of influence aside from government. Their presence may push news coverage in their favor, as it appeared to do in 1981 when complaints by business led to the inclusion of additional tax benefits. And the relative prominence of business sources likely contributes to the overriding anti-tax tone in both newspapers.

Experts were the third most common source overall. They were 9.4 percent of sources in the New York Times, and they appeared even more prominently in USA Today, accounting for 13.8 sources there. In fact, the use of experts as sources represented the only substantial difference that appeared between the Times and USA Today. And the outcome is particularly perverse from the perspective of audience influence. The Times with its strong readership among the nation's cultural and intellectual elite was less likely to include experts as sources than the mass-based, anti-intellectual USA Today, exactly the opposite of the expectation if audiences actually influenced content.

Other sources appeared even less frequently. I coded for labor unions because of the possibility that ordinary citizens may have more influence to the degree that they are organized collectively. And labor unions may be the organized groups most likely to represent the views of ordinary citizens on tax policy. The findings here clearly undermine the notion. Labor unions received some attention in 1981, appearing as sources in 7 articles, or 2 percent of sources in the New York Times that year. That was the greatest attention labor unions received during the period. Labor union references declined to virtual invisibility thereafter, appearing in only one or 
two stories in subsequent years. There was a single reference to a labor union source in the Times in 2016, or a fraction of one percent of sources in the paper that year. There was not even one union representative in USA Today for the entire year. This may reflect the declining political fortunes of labor unions generally. And it suggests that while unions may be regular targets for abuse in the media, they are not permitted to discuss matters of public affairs, even on issues of obvious relevance for their constituencies like taxes.

Interestingly, ordinary citizens actually received more attention than unions, even beating out business for second place in 1990 in both newspapers. Still ordinary people appeared infrequently. They accounted for 7.6 percent of sources in the Times for the entire period, almost exactly half of the percentage of business sources, and one ninth of the percentage for officials. Their presence varied from year to year. They were less visible in years with regressive tax cuts, just 2.8 percent of sources in the Times in 1981 and 6.6 percent of sources in 2001. They were 6.9 percent of the sources in the Times in 2016, quite close to their representation in 2001. But not a single ordinary person appeared as a source in USA Today for the entire year. In fact, every one of the sources in the anti-elitist USA Today in 2016 came from government, business, or the intellectual class.

Ordinary people appeared somewhat more often in years marked by progressive tax increases, 11.8 percent of sources in the Times and 13.2 percent of the sources in USA Today in 1990 and 10.7 percent of sources in the Times and 11.3 percent of sources in 2012. The pattern suggests that ordinary people were likely to advocate for higher taxes when given the chance, that the national newspapers made decisions to highlight or ignore public views according to political circumstance, and that their relative invisibility reflected the newspapers' disapproval of progressive taxes in general. 


\section{Occupy Wall Street and the New York Times}

News coverage of taxes followed some familiar patterns in 2012. Government officials continued to dominate as sources. Business sources outnumbered ordinary people almost two to one. And demands for tax cuts were three times more likely to appear than calls for tax increases on the rich. Still, the newspapers paid more attention to public support for higher taxes on the wealthy, used more ordinary people as sources, and taxes on the wealthy increased at the end of the year. This was not due to any change in public opinion. Public support for higher taxes remained relatively high at 62 percent according to a Gallup poll, but that was near the lowest level of support for the entire 40 year period. Instead, newspaper coverage and tax policy outcomes might have been influenced by the appearance of Occupy Wall Street in the fall of 2011, or it might have been part of a conscious effort by the Obama administration to adopt inequality and tax policy as campaign issues to use in 2012 against the Republican nominee, eventually and fortuitously the plutocratic Mitt Romney ((Ferguson 2014' Ferguson, Jorgensen, and Chen 2018).

To consider these possibilities, I evaluated all articles on taxes in the New York Times for 2011, and I counted all sources and their positions concerning the direction of tax policy. Figure 10 captures the impact of Occupy Wall Street, the Obama campaign, and the scheduled expiration of the Bush tax cuts on Times coverage of taxes. The use of ordinary people as sources and attention to progressive taxes generally moved together. And both measures were unusually high even before Occupy Wall Street. There were 10 articles mentioning public support for progressive taxes in the eight months before Occupy Wall Street appeared, more than for any entire year except 2012. Times attention increased even further during the occupation of Zuccotti Park. There were four front page articles in October while protestors were in the park and four 
more in December and January 2012 after the protestors were forced out. Then Times attention fell below the previous level with only seven articles over the next nine months. Attention spiked again in November and December of 2012 in association with the presidential election and the expiration of the Bush tax cuts at the end of the year.

The relatively intense attention during the fall of 2011 underscores the potential impact of citizen action in exceptional circumstances. However, the number of references to progressive taxes before Occupy Wall Street, the New York Times' comparative silence on the issue after the movement faded from the scene, the spike in attention around the election and the end of 2012, and the overriding reliance on officials as sources all suggest that it was the Obama administration and its presidential campaign that drove the newspaper's attention. Of course, it is possible that Occupy Wall Street inspired the Obama administration to adopt the issue in the first place. And this indicates that social movements succeed when they capture the attention of elites. But it also shows that New York Times takes issues seriously when elites promote them.

\section{Conclusion}

Americans routinely say that they want higher taxes on business and the rich, just as tax burdens for corporations and the wealthy have fallen over recent decades. The national newspapers may have shared responsibility for this outcome. If the mass media represent public preferences, as Gentzkow and Shapiro argued, policymakers may have to acknowledge public opinion and respond to it. However, the national newspapers lavished attention on officials and largely ignored ordinary citizens on tax policy. Occasionally ordinary people appeared on the pages of the newspapers, mostly when they agreed with elites. The newspapers were much more likely to report that citizens wanted tax cuts, and it was much less likely to acknowledge that they also 
favored higher taxes on the wealthy. Ordinary citizens may have appeared in the Times during Occupy Wall Street precisely because President Obama and the Obama campaign promoted progressive taxes as well. More often, supporters of progressive taxes were excluded from news coverage and ignored by elected officials. If media suppress public views, citizens will not be able act on them, and elected officials won't have to respond to them.

Newspaper representations facilitated elite political strategies on taxes. The advocates for the rich overcame public objections by tying unpopular tax cuts for the rich to more popular tax cuts for ordinary people. The newspapers promoted public opposition to taxes, suppressed public support for higher taxes on the wealthy, and conflated taxes on the rich with taxes generally. Policy makers, in turn, cited public sentiment to reduce taxes for corporations and the wealthy, exactly the opposite of the preferences Americans expressed when asked specifically about the possibility. In response to Bartels' claim that supporters of the Bush tax cuts were poorly informed about their consequences, Arthur Lupia and his colleagues (2007) proposed that Americans supported the Bush tax cuts because they saw it as the best choice on offer. The regressive features of the Bush tax cuts were certainly not selected by the American people. Policy makers did not provide an alternative that more closely reflected public preferences in this regard. And the national newspapers obscured the difference between public opinion and policy outcomes.

Newspaper coverage in 2016 closely resembled past behavior, and it signals the likely outcome with respect tax policy in 2017 as well. Americans expressed concern over inequality and favor higher taxes on corporations and the wealthy. Trump proposed large tax cuts for business and the rich that will exacerbate inequality in the future. In this instance, as on tax policy generally, Americans are likely to get exactly the opposite of what they say they want. 
The pattern is clear enough, but some aspects of the relationship between the national newspapers and other elites remain uncertain. It could be that the newspapers simply echoed official views to society as a whole. Or it could be that officials also received signals through the media from media owners and other business interests. The preponderance of official sources underscores the power of government. Business interests might have influence through the use of sources too, but businesses might also seek influence through media owners. Media owners, in turn, may represent other business interests, or they might exert influence in their own right. And there is evidence for the importance of media owners. After all, the national newspapers made many choices of their own: to privilege official sources, to highlight some views and ignore others. The ability of the newspapers to find ordinary people to complain about taxes in one instance or call for higher taxes in another, without any changes in broader public opinion, shows that that the newspapers could find sources to say almost anything to fit the prevailing narrative.

Unfortunately the influence of media owners and business interests may be relatively difficult to detect. And the inability to see it fully here is partly a methodological issue. One possible solution would be to compare front page coverage to newspaper editorials. Editorial opinion may disclose the preferences of the newspapers' owners and other business interests. It may reveal nuances in the newspapers' positions on taxes. The newspapers might oppose taxes on corporations and the wealthy, for example, but favor other forms of taxation. It may show whether the owners disagree with official positions on taxes. Or if they do agree, it might show whether the newspapers echo official positions, or whether they push officials instead. The comparison may further expose the nature of power in society and the role of the mass media in the political process. 


\section{References}

Atkinson, Anthony B. 2015. Inequality: What can be done? Cambridge: Harvard University Press.

Bagdikian, Ben, H. 2004. The new media monopoly. Boston: Beacon Press.

Bartels, Larry M. 2008. Unequal Democracy: The political economy of the new gilded age. Princeton: Princeton University Press.

Bennett, W. Lance. 1990. "Toward a theory of press-state relations in the United States." Journal of Communication, 40: 103-125.

Bennett, W. Lance. 2005. News: The politics of illusion, 6th edition. New York:

Pearson/Longman.

Berelson, Bernard, Paul F. Lazarsfeld, and William N. McPhee. 1954. Voting: A study of opinion formation in a presidential campaign. Chicago: University of Chicago Press.

Brownlee, W. Elliot. 1996. Federal taxation in America: A short history. Cambridge: Cambridge University Press.

Chomsky, Daniel. 1999. "The mechanisms of management control at the New York Times." Media, Culture \& Society, 21: 579-599.

Chomsky, Daniel. 2006. "'An interested reader': Measuring ownership control at the New York Times." Critical Studies in Media Communication, 23: 1-18.

Chomsky, Daniel, and Scott Barclay. 2013. "The editor, the publisher, and his mother: The representation of lesbians and gays in the New York Times." Journal of Homosexuality, 60: 13891408.

Cohen, Bernard C. 1963.The press and foreign policy. Princeton: Princeton University Press.

Cowen, Tyler. 2013. Average is over: Powering America beyond the age of the great stagnation. New York: Dutton.

Diamond, Edwin. 1994. Behind the times: Inside the new New York Times. New York: Villard Press.

Diamond, Peter, and Emmanuel Saez. 2011. "The case for a progressive tax: From basic research to policy recommendations," Journal of Economic Perspectives, 25: 165-190.

Faris, Robert, Hal Roberts, Bruce Etling, Nikki Bourassa, Ethan Zuckerman, Yochai Benkler. 2017. "Partisanship, propaganda, and disinformation: Online media and the 2016 US presidential 
election.” Berkman Klein Center for Internet \& Society at Harvard University, Research Publication 2017-6.

Ferguson, Thomas. 2014. "What's the real reason 'Capital in the Twenty-First Century' is doing so well in the United States?" Alternet, May 16, 2014; www.alternet.org/economy/whats-realreason-capital-21st-century-doing-so-well-us

Ferguson, Thomas, Paul Jorgensen, and Jie Chen. 2018. "Industrial structure and party competition in an age of hunger games: Donald Trump and the 2016 election." Institute for New Economic Thinking Working Paper No. 66, January 2018; https://papers.ssrn.com/sol3/papers.cfm?abstract id=3125217

Gamson, William A. 1992. Talking politics. New York: Cambridge University Press.

Gamson, William A. 2001. "Promoting political engagement." W. Lance Bennett and Robert M. Entman eds., Mediated politics: Communication in the future of democracy. New York: Cambridge University Press.

Gentzkow, Matthew, and Jesse M. Shapiro. 2006. "What drives media slant? Evidence from U.S. newspapers," NBER Working Paper, 12707, November 2006.

Gilens, Martin. 2012. Affluence and Influence: Economic Inequality and Political Power in America. Princeton: Princeton University Press.

Graetz, Michael J., and Ian Shapiro. 2005. Death by a thousand cuts: The fight over taxing inherited wealth. Princeton: Princeton University Press.

Hacker, Jacob S., and Paul Pierson. 2005. "Abandoning the middle: The Bush tax cuts and the limits of democratic control," Perspectives on Politics 3:33-53.

Hamilton, James T. 2004. All the news that's fit to sell: How the market transforms information into news, Princeton: Princeton University Press.

Herman, Edward S., and Noam Chomsky. 2002. Manufacturing consent: The political economy of the mass media. New York: Pantheon.

Iyengar, Shanto, and Donald R. Kinder. 1987. News that matters: Television and American opinion. Chicago: University of Chicago Press.

Kenworthy, Lane 2013. Social democratic America. New York: Oxford University Press.

Klapper, Joseph T. 1961. The effects of mass communication. New York, Free Press.

Lazarsfeld, Paul F., Bernard Berelson, and Hazel Gaudet.1948. The people's choice: How the voter makes up his mind in a presidential election. New York: Columbia University Press. 
Lupia, Arthur, Adam Seth Levine, Jesse O. Manning, and Gisela Sin. 2007. "Were Bush tax cut supporters 'simply ignorant.' A second look at conservatives and liberals in 'Homer gets a tax cut."' Perspectives on Politics, 5: 773-784.

McChesney, Robert W. 1999. Rich media, poor democracy: Communication politics in dubious times. Urbana: University of Illinois Press.

McCombs, Maxwell E., and Donald L. Shaw. 1972. "The agenda-setting function of mass media." Public Opinion Quarterly, 36: 176-187.

Neuman, W. Russell, Marion R.Just, and Ann N. Crigler. 1992. Common knowledge: News and the politics of meaning. Chicago: University of Chicago Press.

Page, Benjamin I. 1996. Who Deliberates? Mass media in modern democracy. Chicago: University of Chicago Press

Page, Benjamin I., Larry M. Bartels, and Jason Seawright. 2013. "Democracy and the policy preferences of wealthy Americans," Perspectives on Politics, 11: 51-73.

Page, Benjamin I., and Robert Y. Shapiro. 1992. The rational public: Fifty years of trends in Americans policy preferences. Chicago: University of Chicago Press.

Patterson, Thomas E. 1994. Out of order. New York: Vintage.

Piketty, Thomas. 2014. Capital in the Twenty-First Century. Cambridge: Harvard University Press.

Porter, Eduardo. 2016. “A dilemma for humanity: Stark inequality or total war.” New York Times, December 6, 2016.

Scheiber, Noam. 2015. "'16 hopefuls and wealthy are aligned on inequality." New York Times, March 30, 2015.

Sigal, Leon V. 1973. Reporters and officials: The organization and politics of newsmaking. Lexington MA: D. C. Heath.

Slemrod, Joel. 2006. "The role of misconceptions in support for regressive tax reform." National Tax Journal, 59: 57-75.

Steinmo, Sven. 1993. Taxation and democracy: Swedish, British, and American approaches to financing the modern state. New Haven: Yale University Press.

Stimson, James A., Michael B. Mackuen, and Robert Erikson. 1995. "Dynamic representation," American Political Science Review, 89: 543-565. 
Zaller, John R. 1998. "Monica Lewinsky's contribution to political science," PS: Political Science and Politics, 31: 182-189. 
Figure 1.

\section{Public Opinion and Taxes}

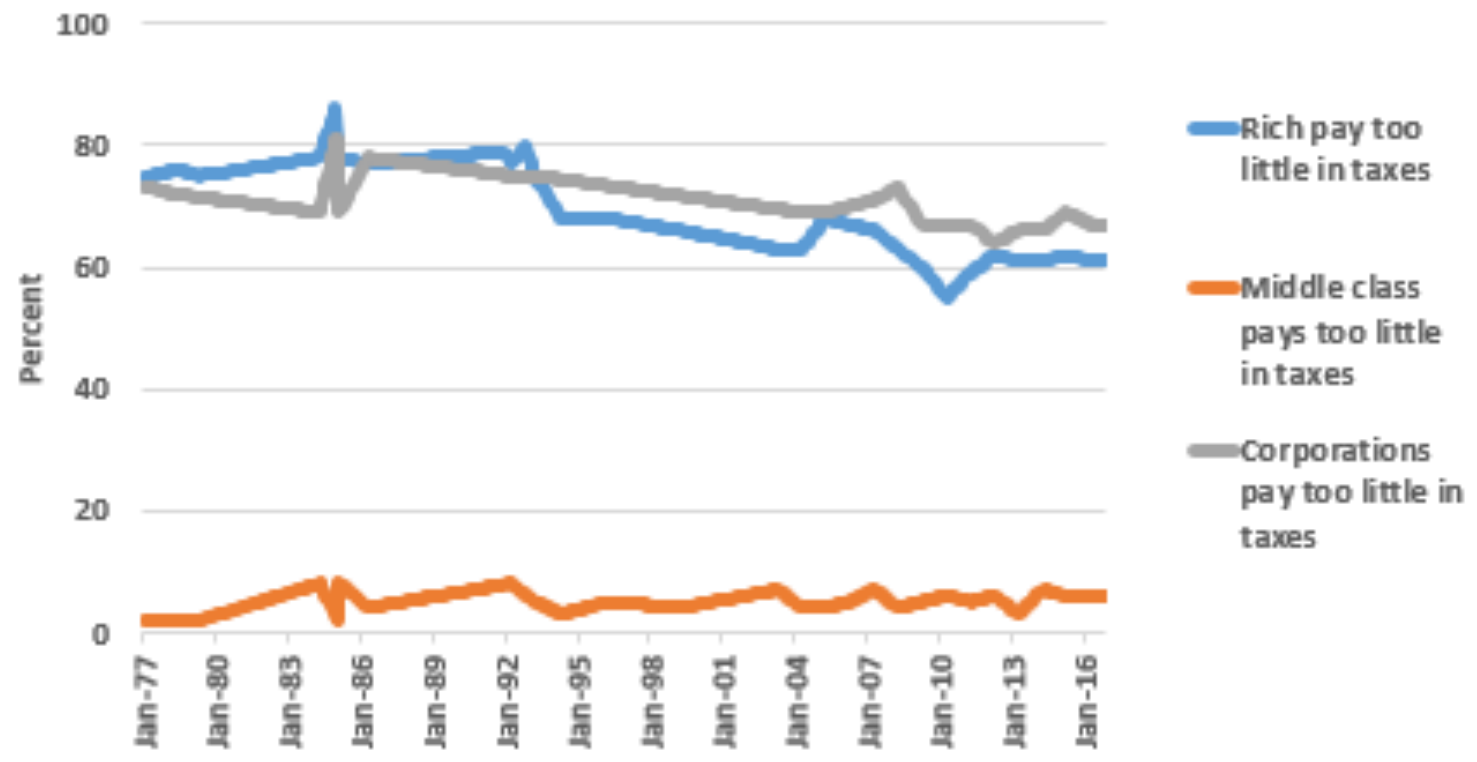

Source: iPOLL 
Figure 2

\section{Public Opinion and the Top Income Tax Rate}

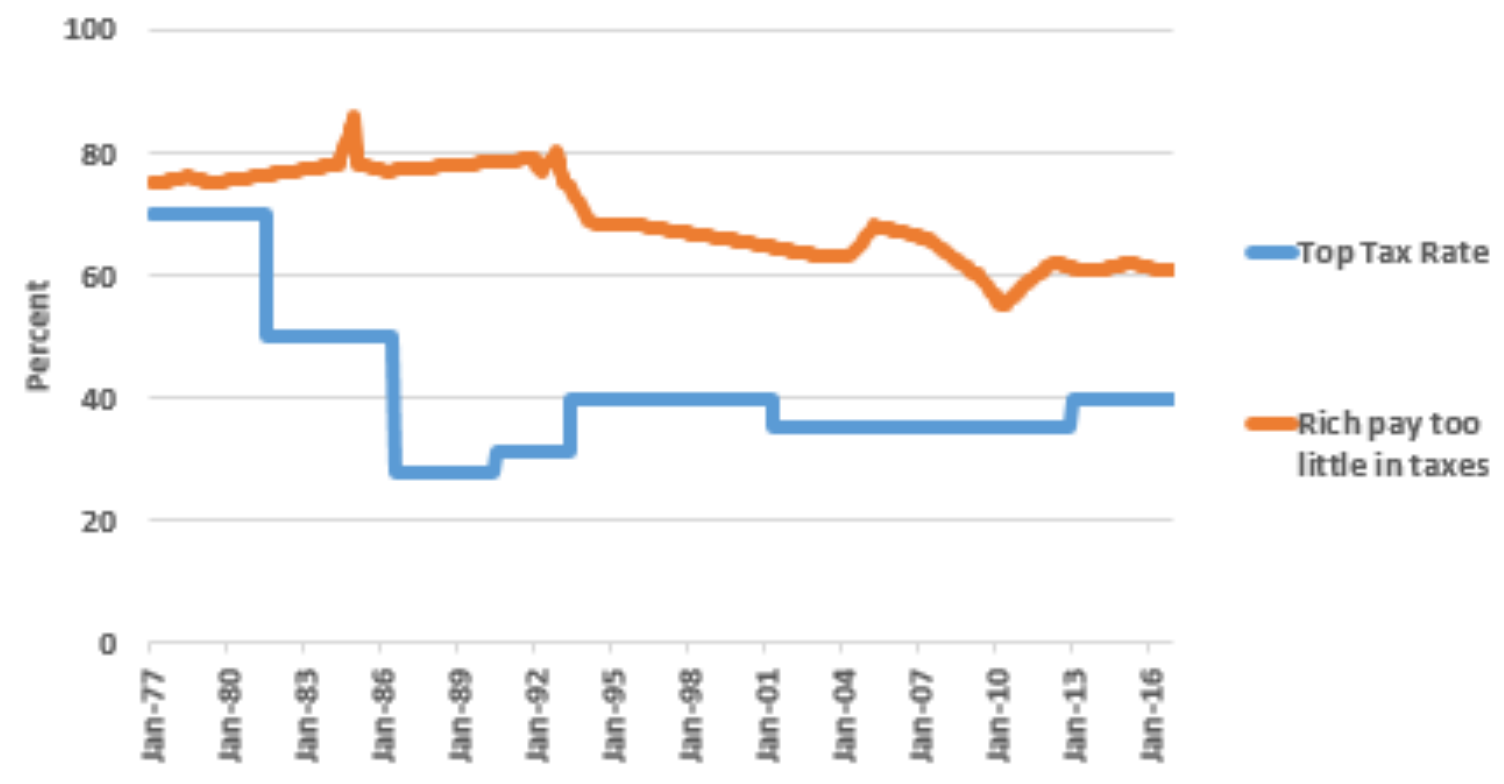

Source: iPOLL 
Figure 3.

Total number of articles, number of articles mentioning public support for lower taxes, and number of articles mentioning public support for higher taxes on the rich, 1990, 2012 \& 2016

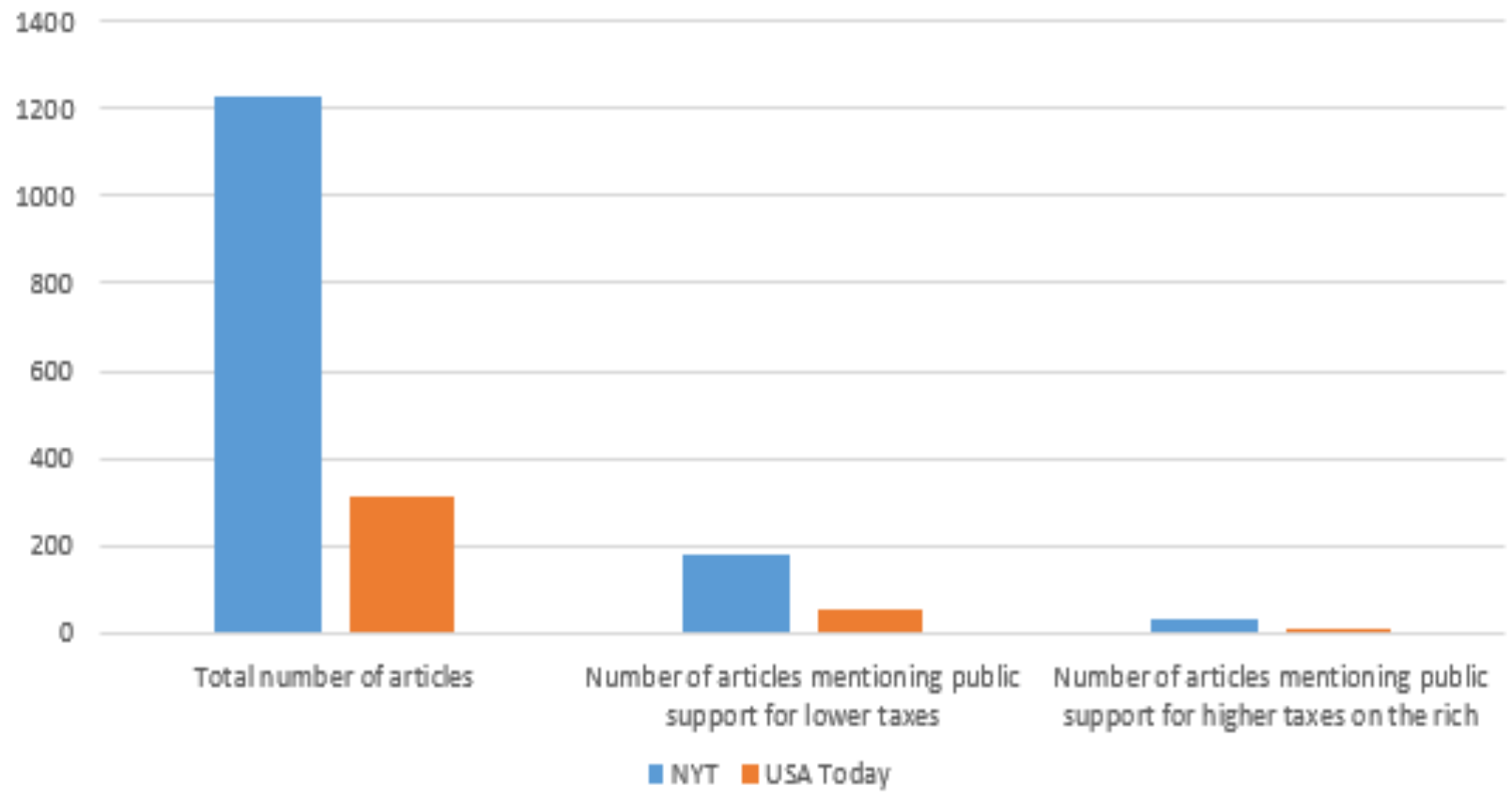


Figure 4.

Percent of articles mentioning support for lower taxes and percent of articles mentioning support for higher taxes on the rich, 1990, 2012 and 2016

20.0

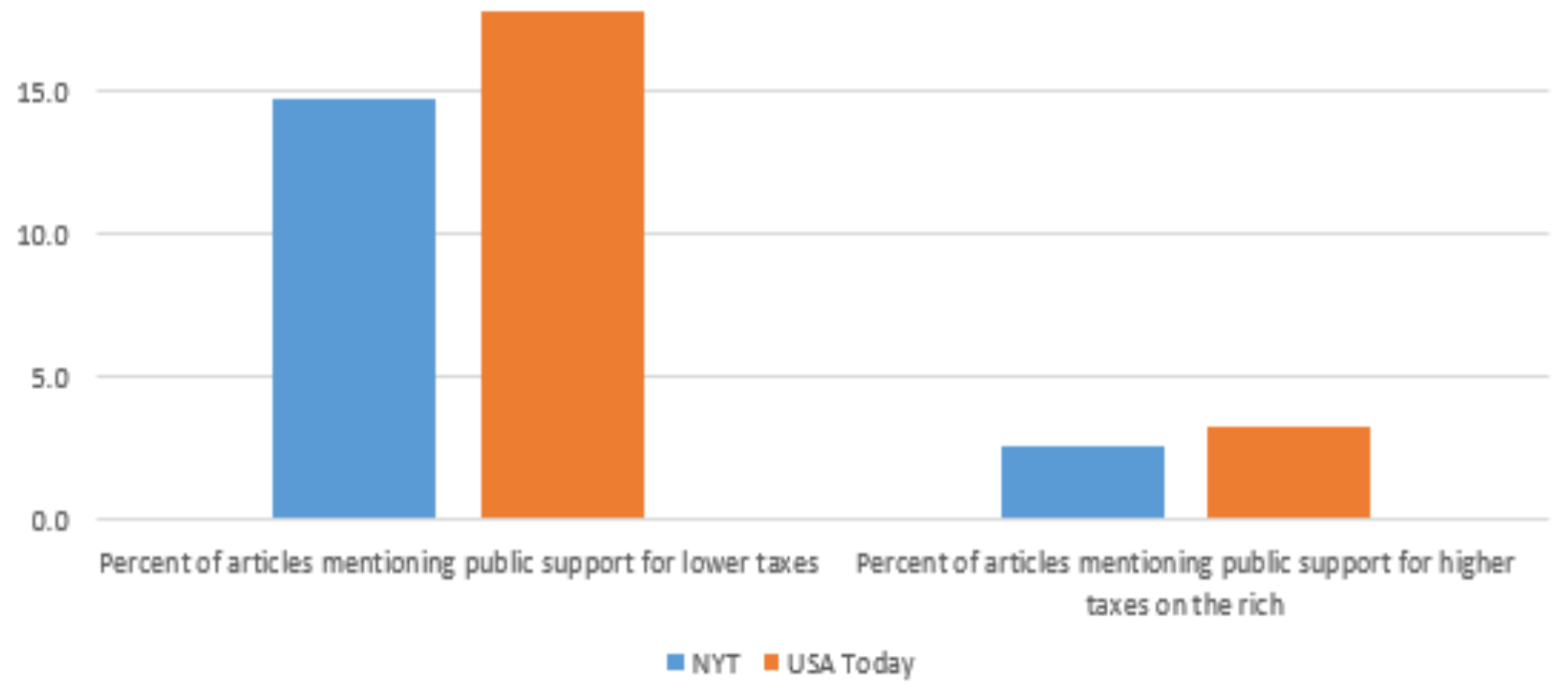


Figure 5.

\section{New York Times Total Number of Articles on Taxes}

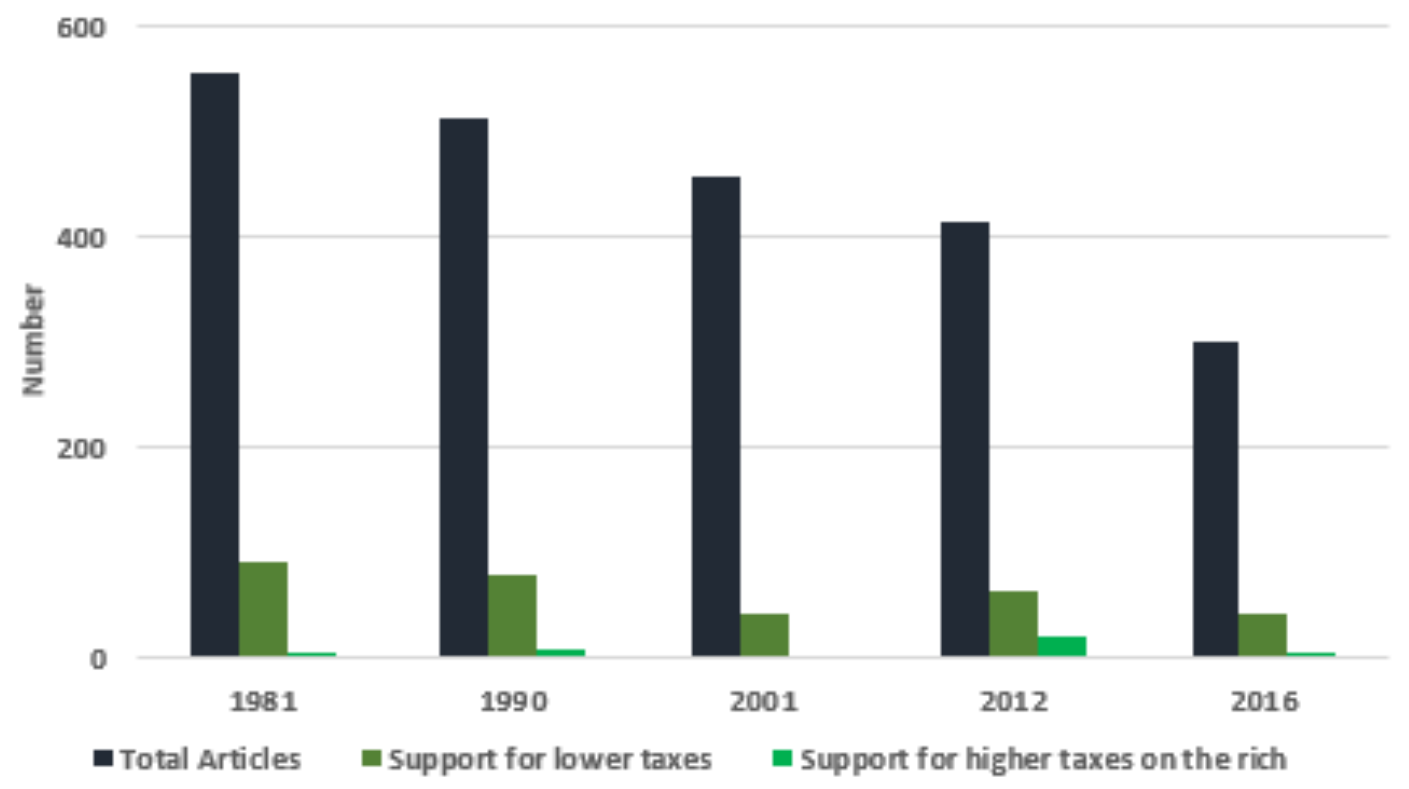

Source: Proquest Historical Newspapers and LexisNexis 
Figure 6.

Number of articles mentioning support for lower taxes, and number of articles mentioning support for higher taxes on the rich, 1990, 2012 \& 2016

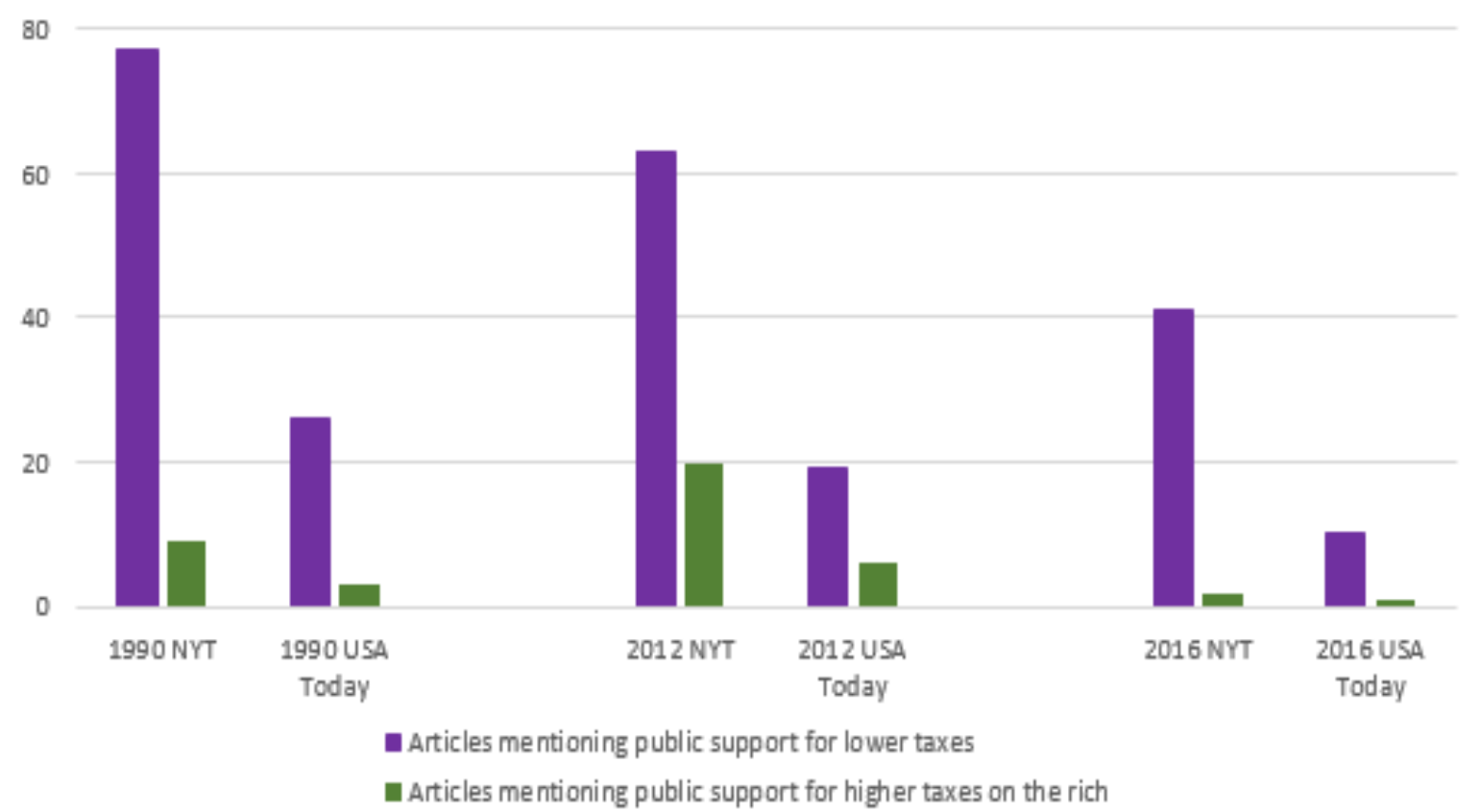


Figure 7.

Sources cited in articles on taxes, 1990, 2012 \& 2016

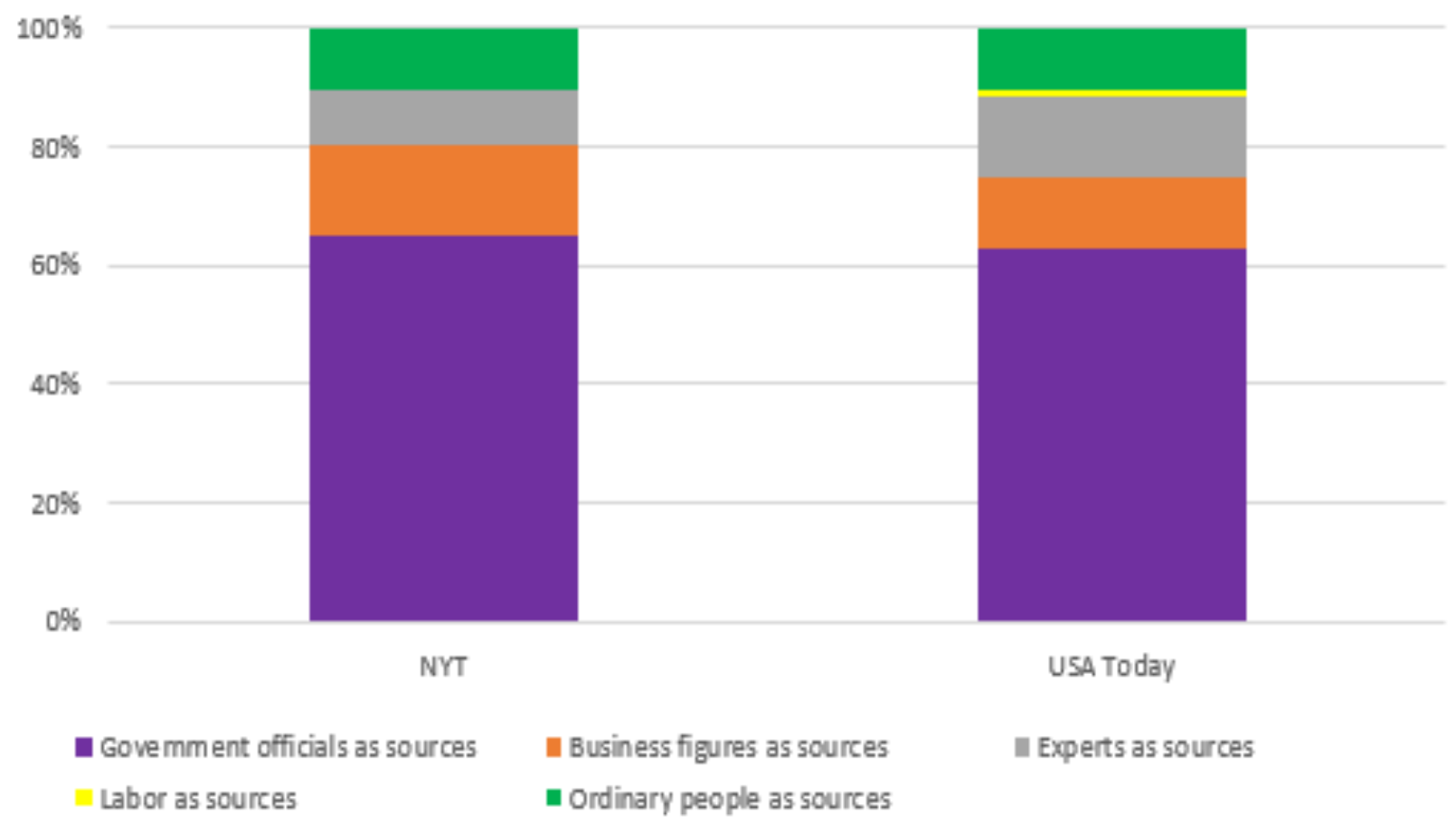


Figure 8.

\section{New York Times Sources Cited in Articles on Taxes}

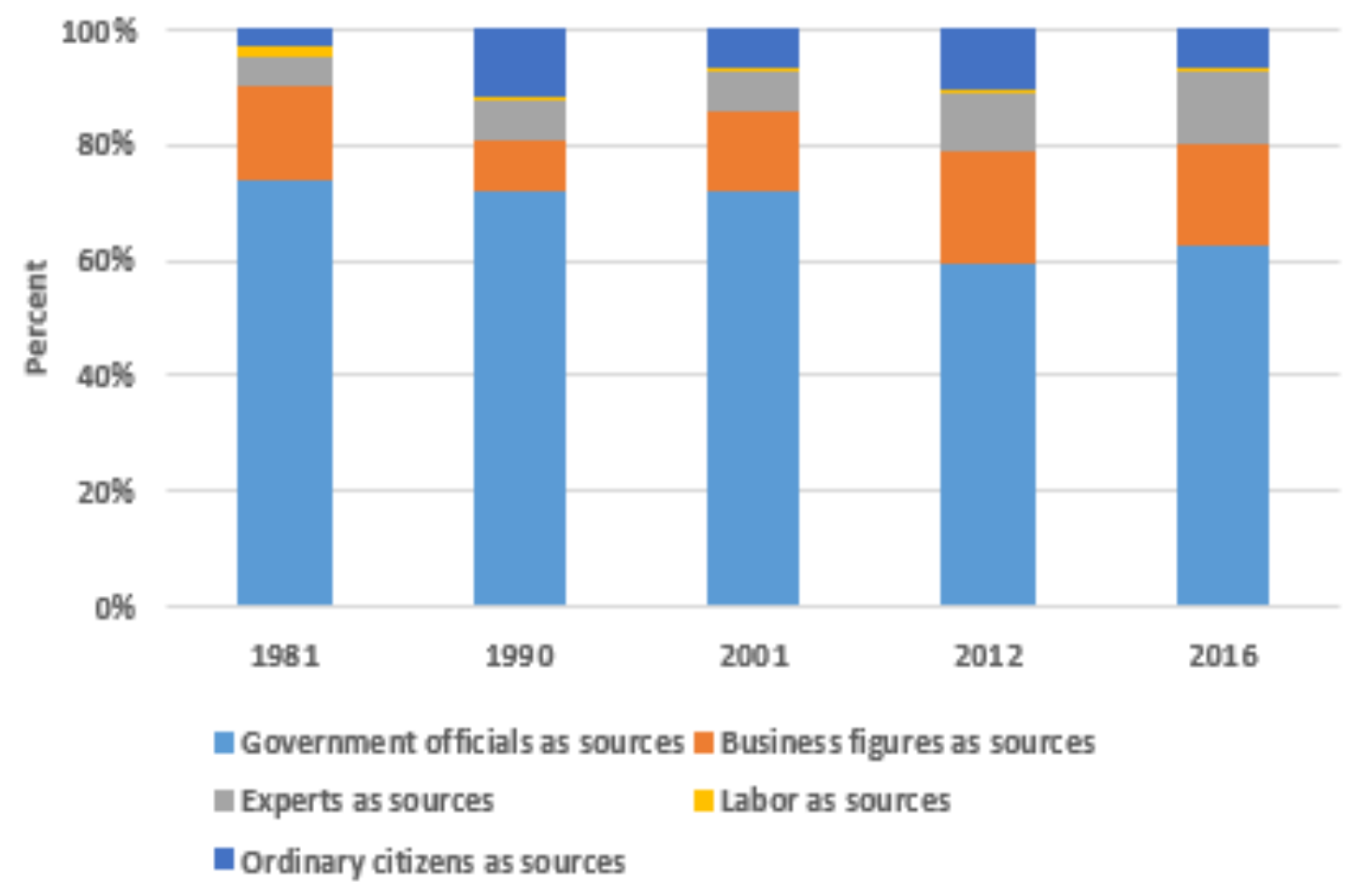

Source: Proquest Historical Newspapers and LexisNexis 
Figure 9.

Sources cited in articles on taxes,

1990,2012 \& 2016

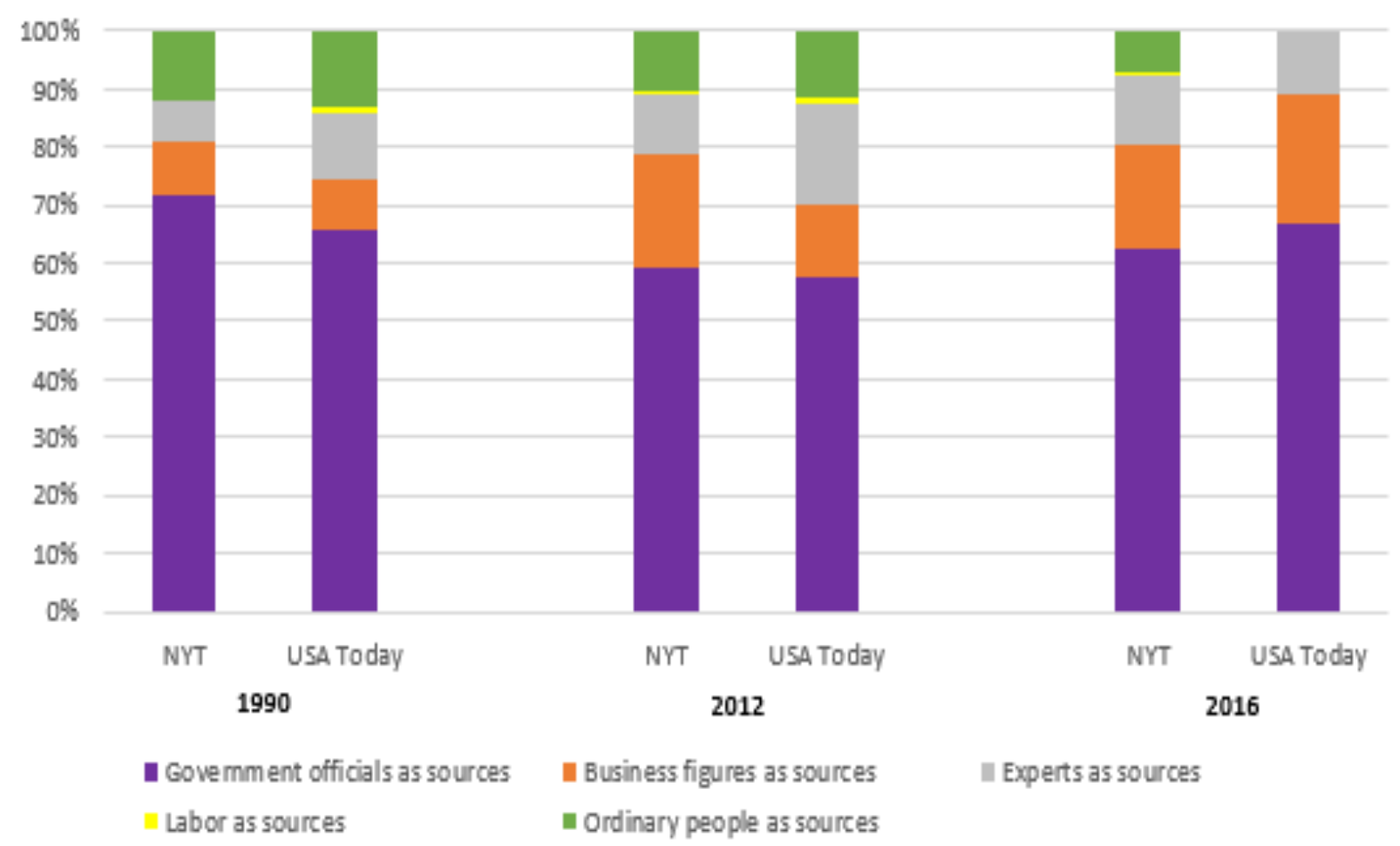


Figure 10.

Number of articles mentioning public support for higher taxes on the rich and citing ordinary people as sources, 2011-2012

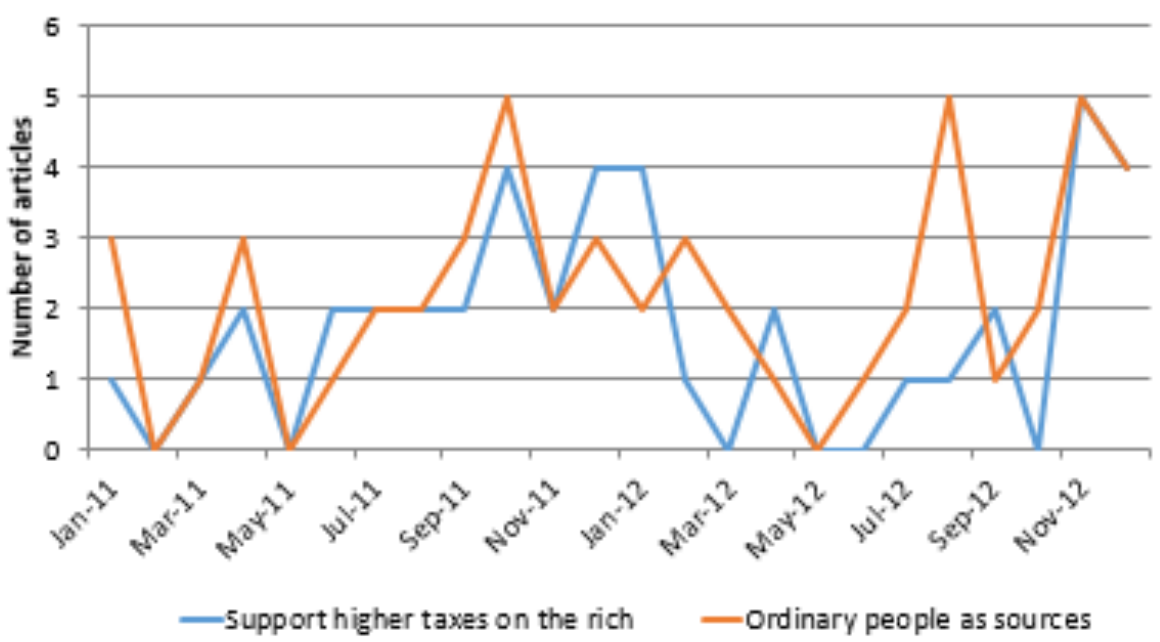

Source: Proquest Historical Newspapers and LexisNexis 